\title{
China's Agricultural Irrigation and Water Conservancy Projects: A Policy Synthesis and Discussion of Emerging Issues
}

\author{
Lijuan $\mathrm{Du}^{1,2}{ }^{1,} \mathrm{Li} \mathrm{Xu}^{3, *} \mathbb{1}$, Yanping $\mathrm{Li}^{3, *}$, Changshun Liu ${ }^{1,2}$, Zhenhua $\mathrm{Li}^{3}{ }^{\circledR}$, Jefferson $\mathrm{S}$. Wong ${ }^{3}$ \\ and Bo Lei ${ }^{1,2}$ \\ 1 State Key Laboratory of Simulation and Regulation of Water Cycle in River Basin, A-1 Fuxing Road, Haidian \\ District, Beijing 100038, China; iwhr_dulj@foxmail.com (L.D.); liucs@iwhr.com (C.L.); \\ bolei1228@hotmail.com (B.L.) \\ 2 China Institute of Water Resources and Hydropower Research (IWHR), A-1 Fuxing Road, Haidian District, \\ Beijing 100038, China \\ 3 Global Institute for Water Security, University of Saskatchewan, 11 Innovation Blvd, Saskatoon, SK S7N 3H5, \\ Canada; zhenhua.li@usask.ca (Z.L.); jefferson.wong@usask.ca (J.S.W.) \\ * Correspondence: li.xu@usask.ca (L.X.); yanping.li@usask.ca (Y.L.); \\ Tel.: +1-306-966-7226 (L.X.); +1-306-966-2793 (Y.L.)
}

Received: 31 October 2019; Accepted: 4 December 2019; Published: 9 December 2019

\begin{abstract}
The United Nations (UN) has identified 17 Sustainable Development Goals (SDGs) to tackle major barriers to sustainable development by 2030. Achieving these goals will rely on the contribution of all nations and require balancing trade-offs among different sectors. Water and food insecurity have long been the two major challenges facing China. To address these challenges and achieve the SDGs, China needs to safeguard its agricultural irrigation and water conservancy projects. Although China is making efforts to transition its agricultural development to a sustainable trajectory by promoting water-saving irrigation, a number of issues are emerging, both with policy reforms and technological innovations. Through synthesizing the historical development of agriculture and its relationship with policy and political regimes, this paper identifies four major issues that are challenging the sustainability transformation of China's agricultural irrigation system and water conservancy projects: (1) problems with financial policy coordination between central and local governments; (2) the lack of incentives for farmers to construct and maintain irrigation infrastructure; (3) conflicts between decentralized operation of land and benefits from shared irrigation infrastructure; and (4) deterioration of small-scale irrigation infrastructure calls for action. In addressing these challenges, policy changes are required: government financial accountability at all levels needs to be clarified; subsidies need to be raised for the construction and management of small-scale irrigation and water conservancy projects; local non-profit organizations need to be established to enhance co-management between farmers and government.
\end{abstract}

Keywords: sustainable agriculture; Asia; China; SDGs; policy synthesis; water management

\section{Introduction}

The United Nations' 2030 Agenda for Sustainable Development identified 17 global goals that integrate traditionally separated social, cultural, economic, and environmental targets into a unified plan of action for people, the planet, and wealth [1]. This set of Sustainable Development Goals (SDGs) advanced the Millennium Development Goals (MDGs) with 169 detailed targets and more than 200 indicators to address major barriers to sustainable development. Among these goals, food, 
and agriculture lie at the heart of the agenda associated with ending poverty (SDG 1) and hunger (SDG 2), responding to climate change, and sustaining natural resources [2].

Water is critical in food production and agricultural practice and thus instrumental in maintaining food security and alleviating poverty [3]. Specifically, water has many uses in agricultural production. It is used to produce and transport energy in different forms throughout the entire 'agri-food' supply chain, such as water storage for irrigation and hydropower generation [4]. Agricultural practices are, thus, critically affected by the availability of water as an input resource via irrigation and drainage systems. According to the Food and Agriculture Organization of the United Nations (FAO) in 1996, approximately $60 \%$ of the extra food required to feed the growing population in the future will primarily come from irrigated agriculture [5]. Water infrastructure projects for irrigation and drainage can facilitate agricultural practices and food production and have synergistic impacts on different areas and cross-sectors. For instance, the expansion of irrigated areas has markedly contributed to crop production in many regions, yet it has also resulted in the sharp decline of groundwater levels [6] and the continuous decrease in the discharge of rivers [7]. As a consequence, there is a need to identify the dynamics between these synergies and relevant factors to balance the trade-offs. If we are to achieve SDGs, at least three changes should occur: the development of a nexus conceptual framework [8], the adoption of new practices by all nations to set them on the pathway to sustainable development, and case comparisons among these nations.

Agricultural issues not only relate to water, but also interconnected with food and energy sectors. All these are set out as three goals (i.e., SDG 2, 6, and 7) in the 2030 SDGs agenda. The rapid spread of green-technology implemented in agriculture in intensively irrigated regions, such as the Ogallala Aquifer area of the central US, has highlighted the interactions among water and energy for agricultural production and food security [9]. There is a growing recognition that water, food, and energy are interlinked and require a systems approach to better understand the interconnections across sectors as a nexus framing [10,11]. The water-food-energy nexus (WFE) was thus conceived in 2011 in the Bonn 2011 Nexus Conference and has drawn global attention [12]. Since then, increasing studies have been conducted to promote sustainable agricultural systems from different perspectives involving policymakers and the scientific community at different scales $[13,14]$. These studies have highlighted the need to consider synergies and trade-offs for more informed decision making. For example, Pittock et al. [15] argued that a nexus approach could be a better cross-sectoral solution to minimize conflicts and realize positive synergies to face climate change in Australia. Other studies linked WFE to other concepts such as livelihood to better promote sustainability [16]. Monblanch et al. [17] used a systems approach combined with scenario analysis to extend WFE to include the broader environmental climate and socio-economic development issues. In addition, WFE has become a buzz word in a number of policy agendas globally and frequently appears in numerous international conferences, such as the decision support report of FAO [18], the World Economic Forum in 2011, and the Bonn and Nexus 2014 conference (see a synthesis in [11]). Although the research of WFE has been dramatically developed in the past few years, the area is still in its infancy. In particular, the application and implementation of WFE need to be further explored $[8,11]$. In their recent paper, Liu et al. [8] proposed a systematic framework to direct future research of WFE to broaden its scope to involve more sectors, across scales and places, and make closer linkages to the implementation of SDGs. Making such a nexus framing practical in operational matters will require a shift of traditional thinking patterns to systems ones and a social transformation to build up coordinated social institutions that recognize interconnections among systems and policy making as well as politics.

For such a radical change to occur, social systems will need to be transformed. The transformation of social systems is defined as the radical change of a society and its social structure involving various sectors such as energy, water management, and agriculture [19]. Most of these changes are non-linear as the ubiquitous interconnections among systems are represented as complicated dynamics over time and across space [20]. In dynamic change processes, paradigm shifts in policy and management 
regimes could be critically important [21], but a recent review of the implementation of SDGs has recognized that policy evaluation is poorly assessed across all countries [22].

To achieve a sustainable future, every country needs to examine all factors and policy barriers involved in reaching this goal. This task is formidable but both necessary and possible [23]. China is playing a leading role in the sustainability transition, in particular, in the realms of green economy development, energy innovation, and vegetation restoration [24,25]. China's policy reforms range from agriculture and land use systems to ecological restoration and provide good examples of how a country can transition to a sustainable trajectory through national-scale programs [26-29]. Synthesizing the historical patterns of interactions between the policy reforms and agricultural systems of China over long timescales can be the key to understanding how today's conditions and problems were created in the past. Studying these historical patterns can help to identify the dynamics and emerging challenges for the sustainability transformation. Given the recent global commitments to SDGs under the UN's Agenda 2030, analyzing how patterns of agricultural systems developed in China is particularly timely.

While several studies have demonstrated the relation between policy changes and the development of agriculture [30-35], understanding how policy interacts with agricultural development in China on a national scale is limited. Synthesizing the development patterns will reveal emerging challenges that the agricultural industry, especially irrigation and water conservancy projects (IWCP), faces in China as the country transitions to sustainability. This paper, therefore, seeks to fill this gap in understanding long-term relationships between agricultural irrigation systems and national-scale policy and political reforms. The remainder of the paper consists of five sections. Section 2 explains the methodology of the paper. Section 3 presents an overview of agriculture in China, including urban-rural population growth, climatic conditions, water allocation, and spatial patterns of grain production. Section 4 integrates the evolution patterns of agricultural development and policy-political regimes since 1949 when the People's Republic of China was founded. Section 5 identifies emerging issues that China needs to tackle to make its agriculture practices sustainable, followed by the concluding remarks in Section 6.

\section{Methodology}

To reconstruct China's development of IWCP and policy-political changes in history and to identify the emerging issues to tackle, we performed a document-based narrative synthesis to retrospectively synthesize policy and political transformations for the detection of emerging issues facing IWCP. Our synthesis follows the narrative (interpretive) review approach $[36,37]$ and the knowledge synthesis process for public policy [38] with the use of policy reports, historical documents, and national statistical data. The narrative review process uses storytelling ways to interpret and synthesize information in a qualitative fashion [36], rather than using historical data to conduct statistical analysis of the correlations. However, we also applied statistical analysis using a piecewise linear regression method to divide the historical patterns of IWCP in combination with document analysis.

More specifically, we first used the National Database from the National Bureau of Statistics of China (http://data.stats.gov.cn/) as the search engine to collect statistical data. We applied "agricultural irrigation" and "water conservancy" (in Chinese) as search strings to retrieve all relevant data about IWCP, and collected a series of policy documents (in Chinese) that related to policy and political changes in history, including the Construction Memorabilia of China (1949-1983) [39], Brief History of China's Agricultural Irrigation and Water Conservancy (1949-1998) [40], and the Chronicle of Events of the People's Republic of China 1949-2019 [41], as well records obtained from official websites of the Ministry of Water Resources (http://www.mwr.gov.cn/) and the China water-saving irrigation network (http://www.jsgg.com.cn/Index/Index.asp). As a result, a dataset was extracted from a series of the China Statistical Yearbook and the China Water Resources Bulletin. These data represent information about population, climate, agricultural irrigation, and crop areas and yields. We then performed a thematic-based content analysis of the documents to organize policy and political reforms in chronological order. In order to divide the development patterns of IWCP in a more convincing way, 
we used statistical analysis to investigate relations between crop yields and irrigation areas to identify change points. As interrupted time series data exist for the effective irrigation areas, a piecewise linear regression method, also known as segmented regression, was applied, which is a regression analysis that allows multiple linear models to be fitted to the data. In doing so, the R package "segmented" was used to objectively identify breaking points and fit a linear regression for each segment over the past decades. The new division of the historical development patterns of IWCP was defined along with changes in policy-political regimes. Several emerging issues and legacies were then identified through the synthesis of these data information and policy documents, as well as sociopolitical reforms.

\section{Overview of Agricultural and Rural Development in China}

\subsection{Population Growth in Urban and Rural Areas}

A prominent factor affecting China's food security and agricultural practices is population growth. Along with its economic reforms, the country's population growth pattern has shifted in the last decades (See Table S1, Figure 1). The economic reforms and the policy of opening-up implemented in 1978 have expedited urbanization, resulting in urban population growth and rural depopulation [42]. In 2010, the number of people living in cities surpassed that of people living in rural areas. Data indicate that, from 2010 to 2018, the number of urban residents increased from 666 to 831 million (59.6\% of the population), while the number of rural residents declined from 674 to 564 million ( $40.4 \%$ of the population) [43].

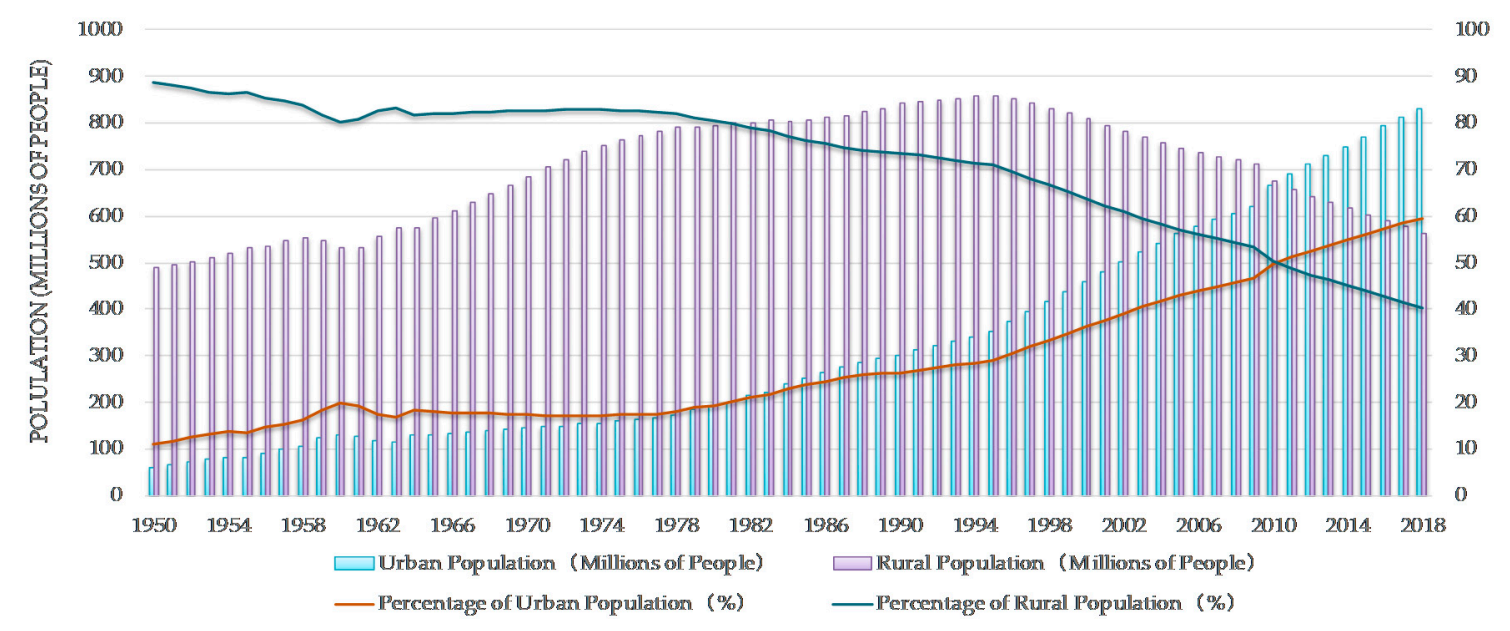

Figure 1. China's urban and rural population structure from 1950 to 2018 [44-46].

Rural-urban migration is the major force driving the shift in the population growth pattern and structure. Rural workers migrating to urban cities to seek work are known as rural migrant workers, a special group of people in China now residing in urban areas [47]. According to the China Statistical Yearbook (2018), the number of migrant workers increased to 242 million in 2010 and exceeded 288 million in 2018 (See Table S2). These migrant workers are usually young, with more than 54\% under 40 [43]. Conversely, those remaining in rural regions tend to be older. These workers prefer to work in farming. As shown in Figure 2, the older people become, the less they are willing to work in non-agricultural positions. About eighty percent of individuals in rural regions farm locally and, thus, dominate the labor force in the group between the ages of 50 and 59. Twenty-one percent of individuals between the ages of 40 and 49 accepted off-farm employment, while the percentage of those farming locally decreased to $67.2 \%$ compared with that of the older group [48,49]. 


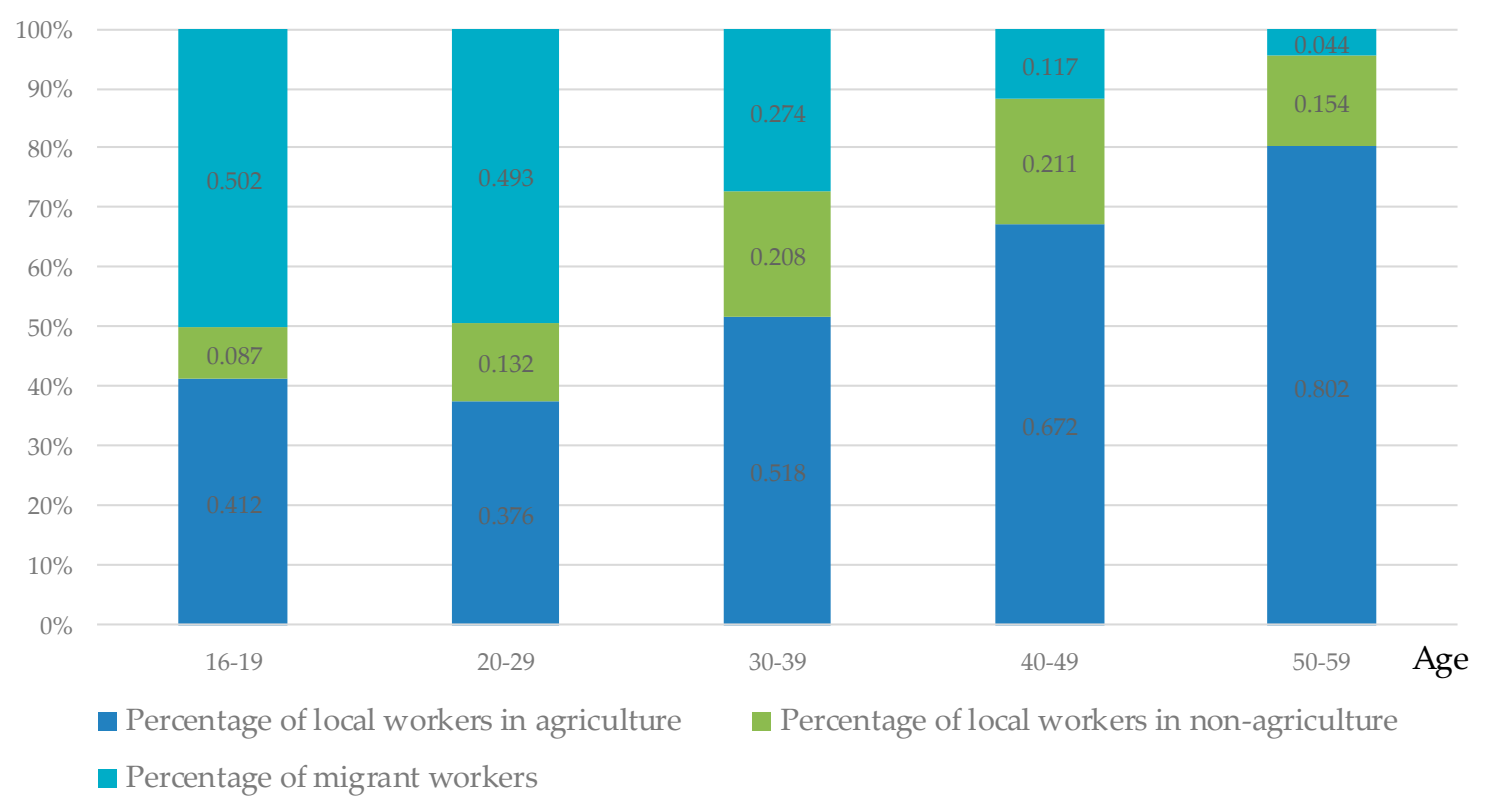

Figure 2. Population structure of migrant workers from 2010 to $2018[48,49]$.

Modern technologies have reduced the size of the labor force required for agricultural production. However, technology's contributions to large farming and agricultural operations are greater than those to smaller operations, largely because there are fewer incentives to smallholder farmers in terms of the input-output ratio involved with adopting new technologies [50]. In China, many farms are less than an acre in size, so they receive minimum benefit from new technologies, and agricultural irrigation and drainage systems still mainly depend on the labor input of rural areas [51]. As mentioned earlier, the population structure has shifted. Starting in the late 1980s, many rural people moved to urban areas, leaving the older people behind as the main labor input in farming activities. Traditional policies, such as the "Compulsory Labor and Accumulated Labor Institution" (Compulsory labor is responsible for afforestation, flood protection, construction, and maintenance of roads and other infrastructure. Accumulative labor has some overlapping obligations as compulsory labor, for example, accumulative labor involves in afforestation, constructing, and maintaining irrigation infrastructure [52]), position local people as the key labor force to manage and maintain irrigation and drainage systems. However, these policies are no longer suitable for the new circumstances represented by the changed population structure and the enhanced level of industrialization that brings more employment opportunities.

\subsection{Climate Conditions and Water Resources}

In addition to the changed patterns of population growth and structure, in China, agricultural production and food security are vulnerable to the spatiotemporal variability of climate and the allocation of water resources. In general, precipitation distribution is different in space and time, intensifying the uneven distribution of water resources in the country. The highest variability of rainfall events usually occurs in spring and the most rain falls during summer when plants need water the most. However, summer rainfalls are usually heavy over the East Asian Monsoon region, causing high frequencies of flooding over major river basins. The south and east regions receive more annual precipitation than the north and west because the latter regions are far from the oceans and the southeast monsoon loses much of its moisture by the time it reaches the northern part of the Loess Plateau. According to the China Water Resources Bulletin [53], in 2016 the sum of surface and groundwater in China was approximately 3246.64 billion $\mathrm{m}^{3}$. Eighty-three percent of this total area is in the south, including the Yangtze and Zhujiang River basins and the basins in the southeast and southwest. The rest of the water $(17 \%)$ is in the north, covering six zones that connect to the 
Songhua River, Liao River, Haihe River, Yellow River, Huaihe River, and rivers in the northwest. Owing to the variations of climate and water distribution, the agricultural zones are divided into three climatic regions: the eastern monsoon, the north-western arid, and the Tibet frigid plateau regions. Although more than $90 \%$ of the country's agricultural products are produced in the eastern region [54], China's agriculture, throughout all of history, has frequently suffered from serious climatic variations. From 206 BC to 1949 AD, more than 1,000 droughts and floods were recorded in China [55].

\subsection{Agricultural Irrigation and Spatial Patterns of Grain Production}

Of all the industrial sectors in China, the most water-intensive is agriculture, which depends, to a large degree, on irrigation and consumes the largest proportion (more than $60 \%$ ) of the national water withdrawal. Irrigation underpins agricultural production, particularly in the dry north, which possesses only one-fifth of the water resources but has about two-thirds of the country's croplands [56]. The country's irrigation infrastructure is mainly in the east, covering the northern regions of the Yangtze River in the middle and downstream, with the rest sparsely located in the northeast provinces, the Xinjiang Uygur Autonomous Territory in the northwest and some coastal provinces (Figure 3). To date, areas equipped for irrigation in China have reached 69.9 million hectares, accounting for about 52\% of total arable land. From 1949 to 2018, effective irrigation has more than quadrupled, from 15.93 to 68.27 million hectares, and, during the same period, the annual grain production increased from 113.18 to 616.24 million tons [56]. Although the expansion of IWCP has enhanced the capacity of agricultural production to meet the growing demand for food, this development appears unsustainable because of the associated environmental impacts. In the Inner Mongolia Autonomous Region and provinces of Gansu and Hebei, where more than $60 \%$ of irrigation relies on groundwater, the depletion of groundwater has sharply reduced the groundwater levels in the last three to four decades [57,58]. Irrigation has also decreased river discharge in arid and semi-arid regions, while increasing pollutants in rivers and lakes [7].

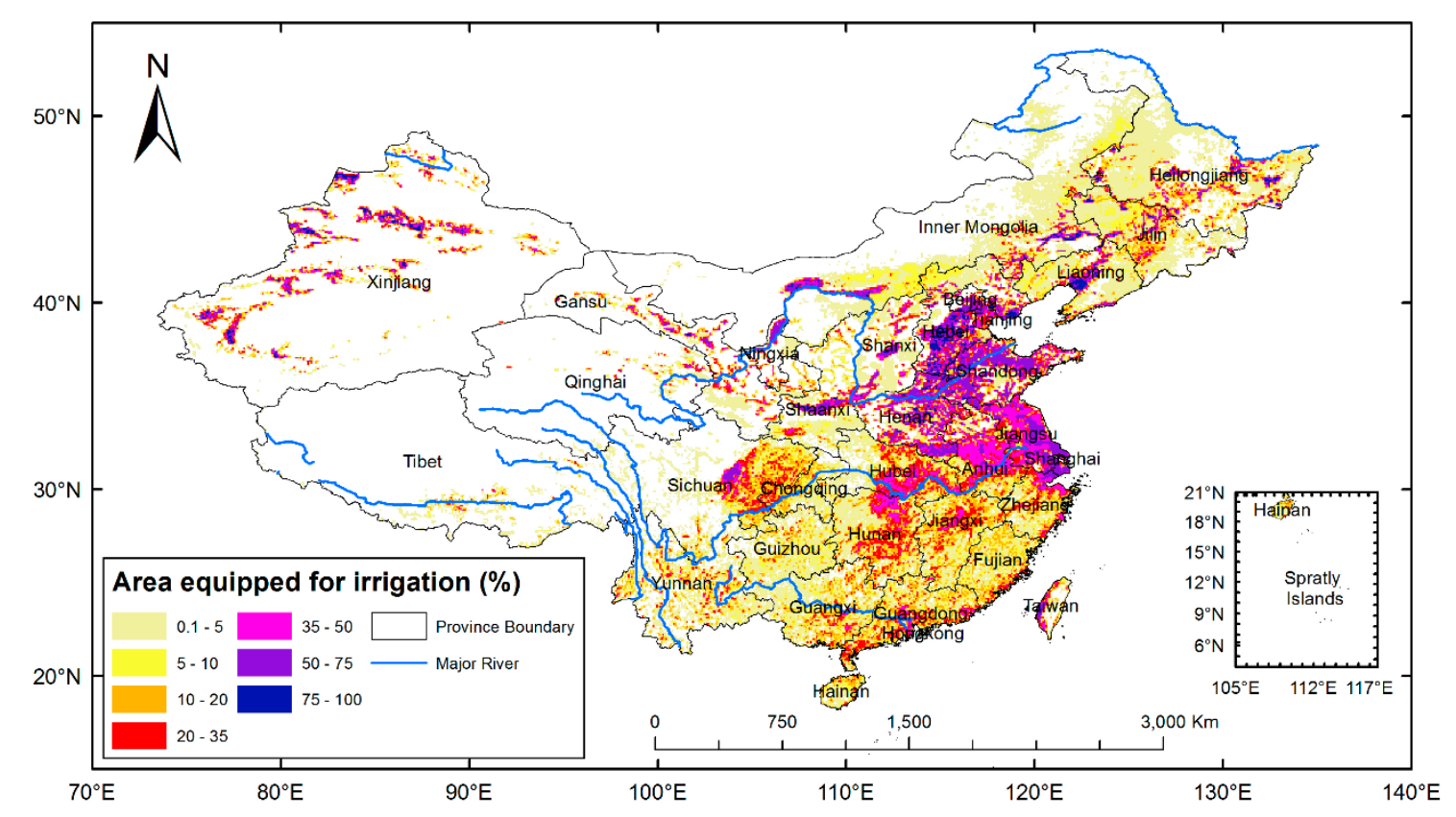

Figure 3. Area equipped for irrigation in China [56].

The spatial patterns of China's grain production are sensitive to not only variations of climate and water distribution but also to land use changes and the massive water projects built for cropping and transportation. In the past, the main crops, including rice and winter wheat, were predominantly produced in southern regions and transported to the north via the Grand Canal (from Hangzhou 
to Beijing), the construction of which started in $486 \mathrm{BC}$. The plain located in the middle and middle-lower streams of the Yangtze River was once the country's core region for grain production [59]. This south-to-north transfer pattern did not shift until the late 1970s, when the 1978 Open Door policy led to a more diverse economy, and core grain-producing regions moved from the provinces of Hunan, Hubei, Guangdong, Zhejiang and Sichuan, and Guangxi Zhuang Autonomous Region in the south to the northeast and west provinces including Heilongjiang, Jilin, Liaoning, and Gansu, as well the Xinjiang Uygur Autonomous Territory. During the same period, coastal regions in the south and east became the key importing provinces [57]. Zhejiang province, where the Grand Canal begins, has now become the second-largest province facing grain shortages, with only $36 \%$ grain self-sufficiency [60].

To improve grain self-sufficiency, several policies and strategies have been implemented at both national and provincial levels since the founding of the People's Republic of China in 1949, including increasing financial investment for innovative farming technologies and improving irrigation and drainage systems. Although improved farming policies and technologies have increased the level of self-sufficiency and growth, the lack of incentives and subsidies for farming, along with the expropriation of farmlands for urban construction, has hampered grain production and agricultural development. Worse still, as a growing number of farmers move to the cities for better housing, education, and other opportunities, the irrigation infrastructure and food supply systems are becoming tenuous and less sustainable. Therefore, there is a need to identify the evolutionary patterns between agriculture and policy reforms to recognize challenges for the sustainability transformation and to find corresponding solutions.

\section{Evolution of Agricultural Irrigation and Policy}

Irrigation in China has a long history, which can be traced back to the Qin Dynasty in 256 BC when Dujiangyan was constructed. Previous studies have divided China's historical path of agricultural irrigation into different eras according to levels of societal demand at the time [61,62]. However, these studies pay little attention to the role of the top-down approach of China's policy-making with its hierarchical and command and control governance system in agricultural development. Therefore, there is a need to reframe the understanding of irrigation development with a specific focus on the paradigm shifts that illuminate the relationship between policy and irrigation development over time.

China's irrigation development is highly influenced by the political and cultural paradigms that govern policy-making and economic planning [63]. In the past six decades, irrigation development in China has undergone different stages, all affected by the policy transitions for rural development and changes in power over management and financial regulation between central and local governments [64]. In this section, we track historical records on policy reforms and changes in China since 1949. We also provide data about irrigated areas and crop yields, which we collected from the Statistical Yearbook of China (1980-2018), China Water Statistical Yearbook (1980-2018), and National Planning for Modern Irrigation Development (2014). The development of agricultural irrigation systems is illustrated using data from the Ministry of Water Resources of the People's Republic of China (http://www.mwr.gov.cn/english/). Then, we mark the critical timing of policy reforms and combine them with data about irrigated areas and crop yields to identify their evolving relations.

Three major policy reforms (the Great Leap Forward policy, the Open Door policy, and Document No.1 of the 2005 policy) were identified which are viewed as three critical changing points of political-policy regimes that greatly influenced the development of IWCP after the establishment of the People's Republic of China. To divide the evolution patterns in a more effective manner, we also perform a statistical analysis of the data using a piecewise linear regression method to estimate the change points (Figure 4). 

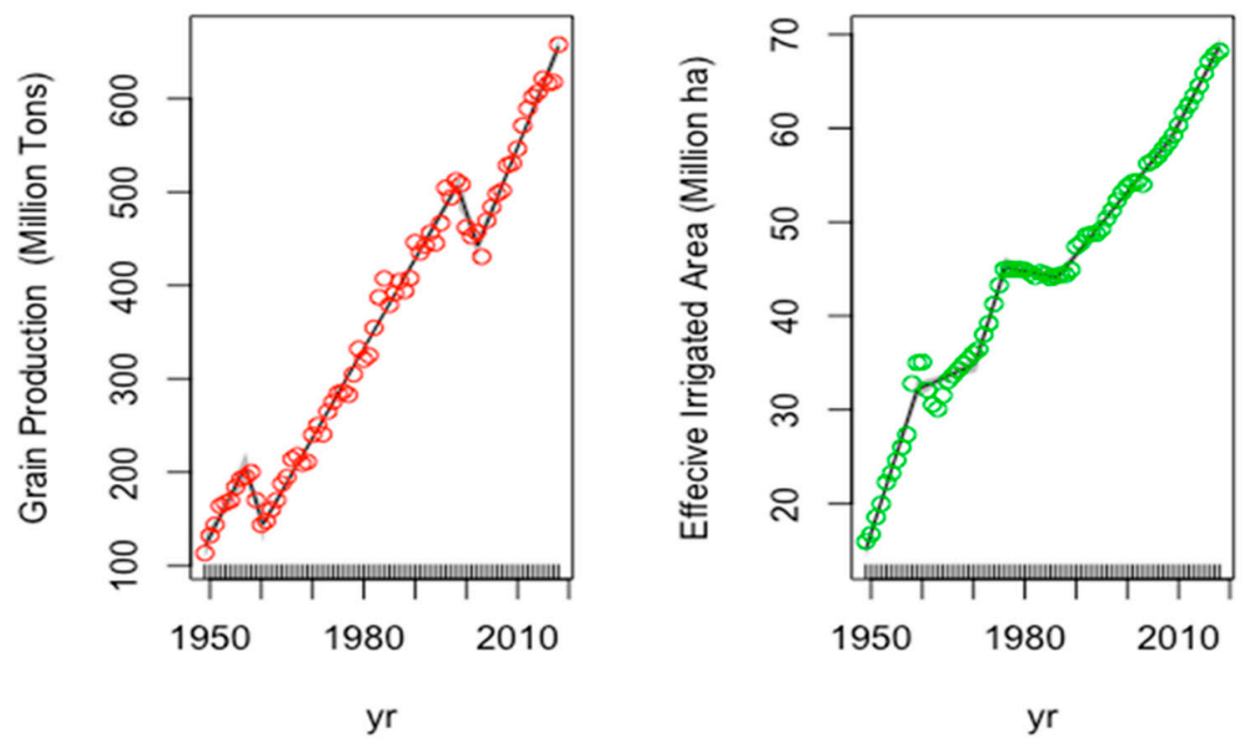

Figure 4. The piecewise linear regressions for grain production and effective irrigated area.

It is not surprising to see the concurrent growth of the effective irrigation area and grain production due to the increasing demands caused by the population explosion since the 1950s. While fluctuations are seen since the establishment of the People's Republic of China in 1949, the general rising trend in both effective irrigation area and crop production is demonstrated by the national statistical data. There is a high correlation $\left(0.955, p\right.$-value $\left.=2.2 \times 10^{-16}\right)$ between the effective irrigation area and crop yield from 1949 to 2018. This is because of the multi-decadal rising trends of both quantities of the two. Among all factors that affect crop yields, it is believed that an effective irrigation area plays a role in crop production while other factors such as agricultural policies, the area of farmlands, and political circumstances have critically contributed to grain production in China. A more meaningful way to analyze the time series of the effective irrigation area and grain production is to investigate the variation of their growth trends due to changes in policy-political regimes and economies. The results shown in Figure 4 illustrate the historical trends in crop production and effective irrigation development in China. As is seen in the figure, historical trends in crop yields can be divided into five periods: 1949-1957 (post-war recovery period), 1958-1960 (declining period during the "Three-Years Chinese Famine"), 1961-1998 (bouncing back period due to agriculture technology advancement and policy reforms), 1999-2002 (declining period due to the price market shock for grains), and 2003-2018 (increasing period because of the national incentive provided for safeguarding grain production and tax reform). The fitting of the effective irrigation area illustrates five breaking points that match the critical policy-political alterations of the country in history: 1959 (the establishment of the People's Commune System), 1970 (suspended since the Great Cultural Revolution until 1970), 1976 (the end of the Great Cultural Revolution), 1986 (the establishment of Compulsory Labor and Accumulated Labor Institution), and 2009 (the implementation of the central finance for irrigation and water conservation projects). Combining the results of the policy and statistical analyses, the evolution of policy and irrigation development is divided into four eras between 1949 and 2018 (Figure 5). This division of the evolution pattern shows how China's agricultural irrigation development has been transforming along with the shifts of policy-political regimes. 


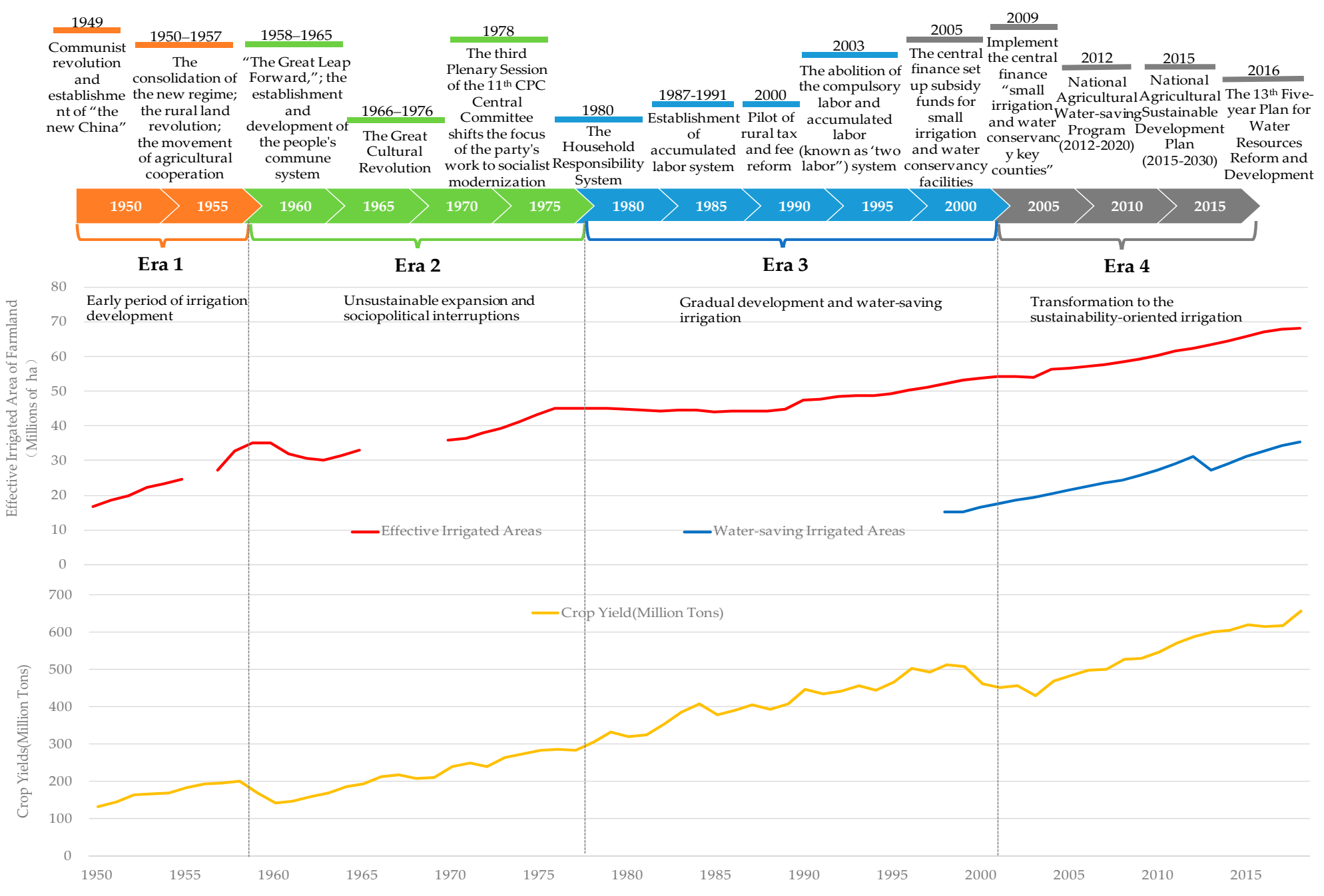

Figure 5. The historical transformation of agricultural irrigation development and policy change in China [39-41,44-46]. 


\subsection{Era 1 (1949-1957): Early Period of Irrigation Development}

With the founding of the People's Republic of China in 1949, the country entered the post-war period during which politicians used policy reforms and economic development to consolidate their political power. At this stage, the national policy agenda's priority was to satisfy people's physiological needs for food, shelter, and clothing. As party leaders focused on the recovery of the country's socioeconomic systems, agricultural development was pivotal. From 1952 to 1956, the central government issued a series of policies and plans. The key movements during this period included the National Development Plan for Agriculture, Agricultural Cooperatives and Collectivization, and the decision to organize local people to construct a series of small IWCP, including small reservoirs, ditches, canals, and wells. At the same time, critical transitions in agricultural production occurred as a result of land ownership and production patterns known as the 'land revolution' and 'agricultural cooperatives movement.' In these movements, individual farmers were progressively organized into people's communes in the form of cooperatives and collectives. These efforts significantly improved the coverage of irrigation and drainage systems throughout the country. According to the China Water Statistical Yearbook 1999 [65], the effective irrigated areas increased from 15.93 million hectares in 1949 to 27.34 million hectares by the end of 1957. The grain output also reached 195.05 million tons in 1957, 81.87 million tons higher than it had been in 1949 (See Table S4).

\subsection{Era 2 (1958-1979): Unsustainable Expansion and Sociopolitical Interruptions}

During this era, the reforms of national policy for economic development and sociopolitical interruptions were instrumental in developing the agricultural irrigation system. From 1958 to 1961, the enforcement of the Great Leap Forward policy and the incremental introduction of agricultural collectivization expanded the agricultural irrigation system. As shown in Figure 4, in 1960 the effective irrigated areas in China reached 35.08 million hectares, an increase of 7.74 million hectares from 1957. However, most of these irrigation projects were poorly planned and built without input from professional engineers with disastrous consequences for the economy and society [66], illustrated by a collapse in grain production and the Great Famine [67].

When the Great Proletarian Cultural Revolution was launched in 1966, most economic activities were suspended for the 'revolution' and the development of IWCP was halted until 1970. In the post-revolution period, a series of policies and decisions were made to offset the negative effects of sociopolitical instability. When it came to the agricultural system, the government's main task was to complete the stagnated infrastructure and improve irrigation facilities in irrigated areas. Benefiting from policy reforms, after 1971, the irrigation system continuously developed. Between 1972 and 1976, the effective irrigated areas experienced a clear increase, even though the north suffered a severe drought period starting in 1972. In response to the drought, the central government allocated resources to 17 provinces in the north to install pump wells for agricultural irrigation. As a result, the number of wells increased from 1 million in 1972 to 2.29 million in 1980. In 1976, the country's effective irrigated areas reached 44.98 million hectares, with wells responsible for 8 million. Meanwhile, the output of grains increased to 286 million tons in 1976 and to 332.12 million tons by the end of 1979 (See Table S4).

\subsection{Era 3 (1980-2004): Gradual Development and Water-Saving Irrigation}

With the implementation of the Open Door policy in 1978, China entered a new stage when industrialization was emphasized as the main mission of economic development in the 1980s. A new policy, known as the Household Responsibility System, was initially directed to agricultural activities in 1979 , which led to major changes in agricultural production and operation. However, the changes made only modest contributions to the development of agriculture and, at the same time, reduced investment in agricultural irrigation. According to the China Water Statistical Yearbook 1979, 1985 [44,68], from 1979 to 1985 , the effective irrigated areas declined from 45 million hectares to 44.04 million hectares. 
During this period, the irrigation system was confronted with many problems, such as a lack of maintenance and farmland conversion for industrial and urban development.

Other reforms took place in the 1980s and 1990s. In the mid-1980s, the water-saving irrigation system was transformed with technical innovations. Between 1980 and 1991, the government established new policies that affected irrigation, including the Compulsory Labor and Accumulated Labor Institution, and reforms of the taxation system. These policies directed resources into maintaining and managing rural irrigation systems and reforming the taxation system for rural areas. The government also embarked on a reform of water use policy to address conflicting water use between industry and agriculture, as well as between urban and rural areas. As a result, from 1980 to 2004 the irrigated areas gradually increased from 44.89 million to 56.25 million hectares (See Table S4). However, because agricultural workers and farmers take time to adapt to technical innovations, crop yields fluctuated during this period.

\subsection{Era 4 (2005-present): Transformation to the Sustainability-oriented Irrigation}

With further development of water-saving technology, in 2005 the central government issued Document No. 1, which elaborated a strategic plan of subsidies for developing small agricultural IWCP. The development of agricultural irrigation was prioritized again in the national policy agenda. Several nationwide policies were launched from 2012 to 2018, including the National Agricultural Water Saving Program (2012-2020), the National Agricultural Sustainable Development Plan (2015-2030), and the 13th Five-Year Plan for Water Resources Reform and Development, all of which highlighted sustainability as key to the development of agriculture and water resources in years to come. In addition to emphasizing irrigation's sustainability, these initiatives included strategies to construct water-saving infrastructure for medium to large irrigated areas, to develop demonstration projects for water-saving irrigation, to set quotas for utilization, to monitor plans to limit water use, to prevent and control agricultural non-point source pollution, and to rapidly transform agricultural production from one that consumes nonrenewable resources to one based on sustainability. These policy reforms have contributed to two changes: the rapid development of agricultural irrigation and the transition of agriculture to a sustainable industry.

To date, over 300 counties have been developed under the core water-saving irrigation program, and 18 cities have been assigned to be demonstration areas for water-saving irrigation. Over the past decade, the effective irrigated areas have expanded by more than 10 million hectares, and, in 2018, it increased to 68.27 million hectares (See Table S4), half of which were based on water-saving irrigation projects. Similarly, from 2003 to 2018, the output of grains improved from 430.70 to 657.89 million tons. In its recent plan (National Agricultural Sustainable Development Plan, 2015-2030), the Chinese government aims to increase the proportion of water-saving irrigation areas to $75 \%$ of the total effective irrigated areas and the level of water use efficiency for irrigation to at least 0.6 by the end of 2030 .

\section{Emerging Issues in the Process of Transformations}

China's history of agricultural irrigation illustrates the government's gradual awareness of the need for sustainable water use in agricultural production. However, a number of issues and legacies are emerging that could hamper the sustainable development of agriculture [69]. In this section, we identify, based on the statistical data, four emerging issues that have to be overcome. They are (1) problems with the financial policy coordination between central and local governments; (2) the lack of incentives for farmers to construct and maintain irrigation infrastructure; (3) conflicts between the decentralized operation of land and benefits from shared irrigation infrastructure; (4) deterioration of small-scale irrigation infrastructure calls for actions.

\subsection{Problems with Financial Policy Coordination between Central and Local Governments}

China's reforms of its fiscal and tax system began in the early 1980s. These reforms had significant impacts on agricultural development because investment in IWCP is a key part of the central 
government's fiscal budget [70]. Yet the reform of the financial system changed rules of budgeting and revenue allocation and obscured the accountability of allocating public finance between central and local governments.

As illustrated in Figure 6, China's fiscal system before the Open Door policy had been highly centralized, with the revenue collected and allocated by the central government [70,71]. In 1980, the Chinese government started to reform this traditional fiscal system, aiming to decentralize power to provincial and local governments [72]. When the reforms began, the central government made a major effort to create a contracting system that encouraged provincial and local governments to develop a regional economy and empowered them to collect and allocate revenues. However, the contracting system reduced the central government's revenues, resulting in less investment for IWCP.

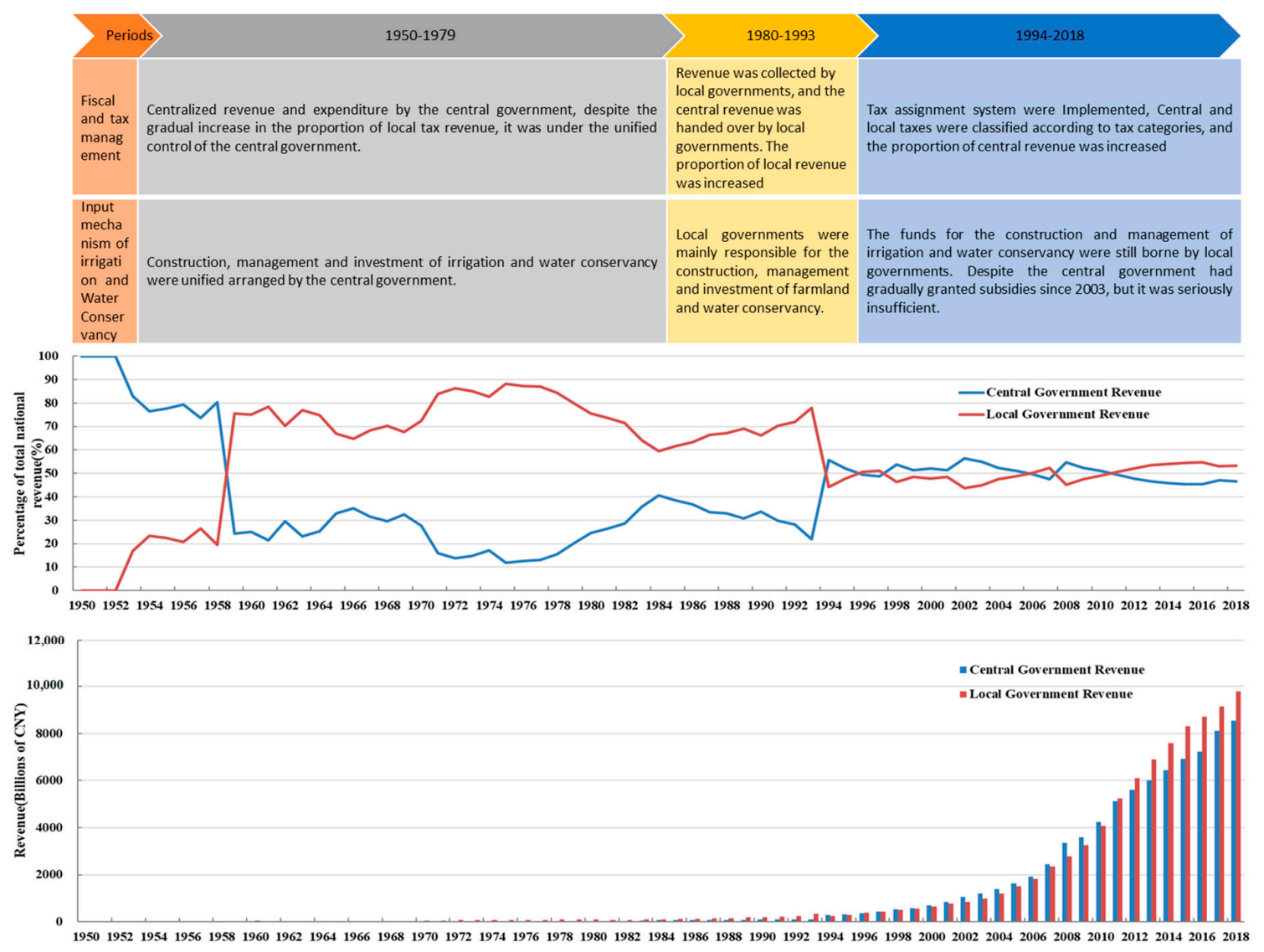

Figure 6. Changes in central and local financial revenue and investment in agricultural irrigation and water conservancy from 1950 to 2018 [73,74].

In 1994, the central government started to shift its policy to create a 'tax assignment system.' The new system recalled a portion of the power that had been given to provincial and local governments. The aim was to (1) simplify the tax structure through reducing tax categories and rates, (2) raise the central-to-total revenue ratio, and (3) shift the negotiation of general revenues to a tax assignment system [43]. The reformed fiscal system narrowed the gap of revenue allocation between the central and local governments.

Although the reform of the fiscal and tax systems in the 1990s partially returned financial power from local governments to the central government, the accountability for investment in IWCP was not clarified. Local governments still mainly invested in constructing and managing IWCP, leading to ambiguity about accountability and financial rights between central and local governments [75]. Recognizing this issue, the central government started to issue subsidies to local governments in 2003. The subsidies allocated by the central government to small-scale IWCP in 2005 totaled 300 million 
Chinese Yuan (See Table S6), accounting for less than $0.1 \%$ of the fiscal expenditure budget for the year. This proportion of investment is much lower than that of $1.87 \%$ in 1980 [73,74]. Although the subsidies were increased to 4.5 billion Yuan ( $0.59 \%$ of the fiscal expenditure budget) in 2009 [43], they are still insufficient to meet the growing farming demands for IWCP construction.

To overcome problems with policy coordination between governments, a multi-level governance system with clearer financial accountability is required, along with policy reforms clarified to governments at all levels. A multi-level governance system, which refers to a cooperative governance system that involves different governance actors on different levels of society to deal with common properties [76], should be introduced to facilitate the coordination between governments and among local farmers, other stakeholders, and government agencies. Although it may be challenging when such a governance system is implemented in the Chinese context, it has become a need and is both appropriate and feasible as argued in recent papers by Ongaro et al. [77] and others [78]. Building a multi-level governance system needs to consider issues relevant to horizontal and vertical coordination among actors, which means that actors should be able to cooperate within the same level and across different administrative and jurisdictional scales. This can be promoted by increasing participation and collaboration of diverse actors, improving accountability, enhancing leadership, and creating networks for collective actions at different levels. At the horizontal level, for example, diverse actors with different skills and resources and cross-sectoral stakeholders such as farmers, private firms, nonprofit organizations, and governmental agencies should be encouraged to participate in the management activities to improve the effectiveness of the implementation of policies. Vertically, actors at both bottom and upper levels should interact through negotiations and cooperation processes via network and leadership groups to ensure a better distribution of responsibilities and resources. For instance, the shared proportion of investment may be adopted by governments at all levels to clarify the financial accountability ensuring the efficiency of investment for IWCP.

The central government should be largely accountable for the investment in IWCP, while the other accountabilities should be proportionally shared by local governments according to the tax revenue as a percentage of gross domestic product (GDP). Both central and local governments should continue to implement and raise subsidies to support farmers to construct and maintain IWCP. Given that most small irrigation systems in China are non-profit and serve as public infrastructure for local farmers, government subsidies should be prioritized for small-scale IWCP operated by and beneficial for local individuals and groups of farmers.

\subsection{Lack of Incentives for Farmers to Construct and Maintain Irrigation Infrastructure}

Since 1949, the construction and maintenance of IWCP in China have mainly relied on the labor of local farmers. However, this operation pattern is no longer suitable for the changed socioeconomic circumstances. Farming activities comprise increasingly smaller portions of household incomes. According to [79], farmers' earnings from irrigation farming activities are now marginal and far lower than wages earned from off-farm employment. It is thus not surprising that farmers are no longer motivated to construct and maintain irrigation infrastructure.

Opportunities for off-farm employment have increased as the economy has strengthened. Figure 7 demonstrates that off-farm employment has become the main source of farmers' incomes in rural areas, and the proportion of non-farm earnings rose to $41.02 \%$ in 2018 from $18.15 \%$ in 1985 . The proportion of agricultural incomes has dropped from $74.44 \%$ in 1985 to $26.61 \%$ in 2012 [44-46], illustrating that agricultural production has contributed less and less to farmers' incomes over the decades. The increased earnings from off-farm work and changed income composition demotivate farmers to construct new irrigation infrastructure and maintain the existing systems for cropping. 


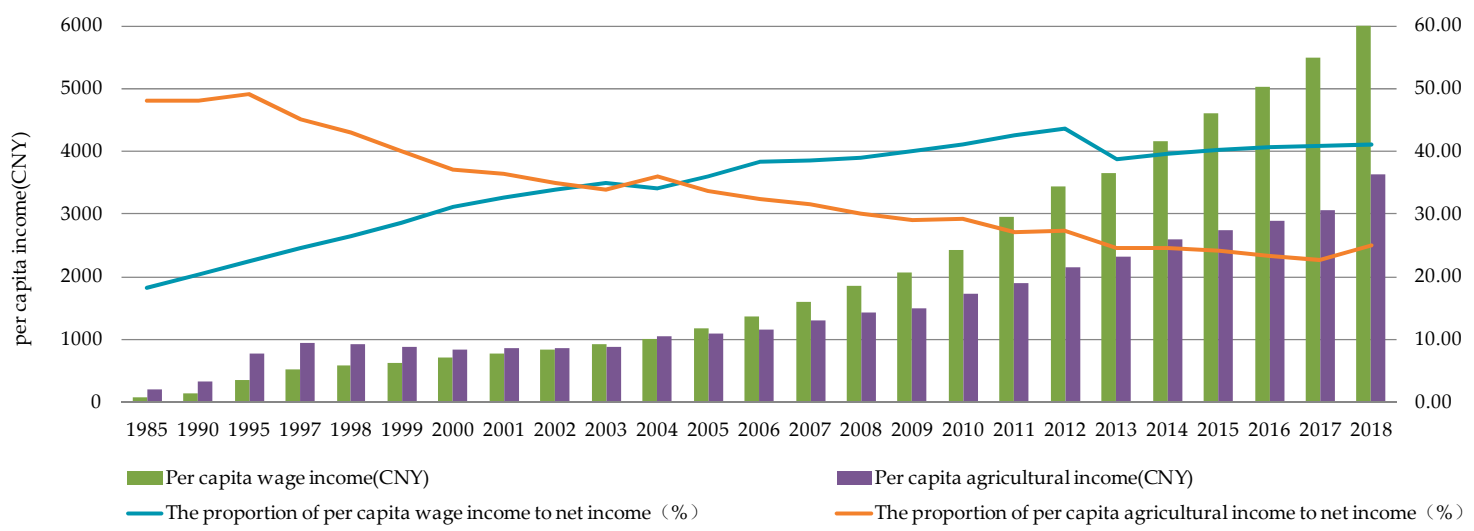

Figure 7. Per capita wage income and agricultural income from 1985 to 2018 [44-46].

In addition to job opportunities off the farm, the lack of efficient policy support and economic incentives reinforces farmers' negative attitudes towards agriculture. In the 1990s, the central government legislated the Compulsory Labor and Accumulated Labor Institution, which successfully organized local farmers to construct and maintain IWCP $[80,81]$. However, this institution was abolished in 2003 when the government enacted its rural tax reform known as the Tax-for-Fee Reform [82]. Although these reforms have eased farmers' burden, insufficient economic incentives and ineffective policy remain, making local government less powerful in organizing farmers to manage irrigation systems. Although, since 2003, the government has started to increase financial support for small IWCP, losses caused by the decline in labor input from local farmers cannot be offset by increased financing.

For farmers to be motivated to return to their work on IWCP, co-management between local farmers and governments needs to be more efficient. Top-down and centralized management has been viewed as an ill-suited manner to user participation [83,84]. Participatory planning and co-management have emerged to be the core for stakeholders and communities to participate in the decision-making processes. Although participatory approaches have also been introduced into Chinese development practice and research in recent years [85], this planning technique is still poorly implemented, especially in rural and countryside regions, for issues and conflicts related to agriculture and farmers. The core of co-management between government and local farmers is power-sharing [86], which requires the sharing of power and responsibility between the government agencies and local farmers. This co-management usually needs to be secured by reliable partnerships in which social trust has been built among government agencies, local communities, and stakeholders. In China, such social trust is rarely established. To improve the bonding relationships for effective co-management practices, bridging organizations such as non-government and non-profit social groups would play a critical role. For IWCP of China, co-management practices should be set up to include and bridge organizations [83], such as local non-profit groups like the Water Users Association. Although participatory irrigation management was introduced to China in the 1990s, through the establishment of the Water Users Associations, the roles these organizations play in constructing and managing IWCP need to be acknowledged and further strengthened through sufficient financial and policy support [87]. For example, the central government could issue supportive policies and provide financial compensations for the local non-profit organizations to organize farmers working on managing IWCP and farming activities.

\subsection{Disparity between the Decentralized Operation of Land and Shared Irrigation Systems}

Since the Open Door policy was launched in 1978, China has initiated multiple policy reforms, among which Rural Land Reform was introduced in 1979 to deal with food shortage crises. The traditional collective-farming policy was then replaced by the Contract Responsibility System characterized by decentralized agricultural production and the operation pattern for farmlands, 
allowing households to contract land, machinery, and other facilities from collective organizations [88]. Under this system, farmers were allowed to produce crops by themselves and freely dispose of surplus production over the collective quotas [89]. The institutional reform of agricultural production significantly raised farmers' willingness to produce greater yields.

However, decentralized land and agricultural production caused a disparity between the benefits farmers gained from the operation and their obligations to maintain shared irrigation infrastructure. In many parts of the country, 'free-rider' problems exist in agricultural irrigation production. The reasons for this problem are two-fold. First, irrigation systems built under the collective-farming policy in previous periods are regarded as public facilities from which nobody can be excluded and which can be freely used by all farmers. Although farmers take the benefits of using the infrastructure for granted, they often neglect to pay more than they have to for the management of this public facility. Second, the lands reassigned to each household from the originally collectively-owned lands are relatively small. The average area of croplands per household in recent years has been about 0.5 hectares [79]. Farmers are thus less likely to be incentivized to pay extra for the maintenance of the shared irrigation infrastructure.

In addressing the disparity between the decentralized operation of land and the shared benefits of irrigation systems, further reinforcement of land transfer and circulation policy, as well as moderate-scale agricultural operations are needed. We suggest that regulation reforms be undertaken to diversify the operation and management patterns of farmlands. These reforms need to empower farmers with the right to transfer their contracted land in different ways under the regulations and to encourage smallholder farmers to develop eco-agriculture projects, such as green agriculture and agri-tourism businesses. These transformations of operational patterns would potentially increase farmers' income levels, thereby motivating them to develop and manage IWCP.

\subsection{Deterioration of Small-scale Irrigation Infrastructure Calls for Actions}

As technology has developed and the economy has expanded, much of China's irrigation infrastructure has improved. The current irrigation infrastructure is comprised of large programs and sturdily built of concrete, iron, and tubing materials. Although modernized engineering technology has benefited medium to large irrigation projects, it has not helped bolster small-scale irrigation infrastructure, which in many parts of China is deteriorating. Most irrigation infrastructures, particularly small irrigation systems built before 1980, were constructed by untrained local farmers using low-quality materials such as mud, stones, and a mixture of sand, water, lime, and cement [90]. An increasing number of small-scale irrigation systems are aging and no longer in service because they have not been maintained. They require reconstruction or renovations to secure food and water systems. Since the construction of IWCP is transitioning from a labor-intensive to capital-intensive activity with no more than $10 \%$ of labor input [91,92], there is a clear and urgent need for governments to increase investment in producing capital to overcome the problems of aging infrastructure.

\section{Conclusions}

China has been confronted with many challenges associated with water and food. Safeguarding irrigation and water conservancy projects for agricultural development is a pathway to solve its water and food insecurity and is essential for achieving the SDGs that require contributions from all nations. The agricultural and water policies of China in the past decades have largely relied on land reforms and the construction of irrigation and drainage systems. These reforms and infrastructure have significantly contributed to the dramatic growth of the economy and social welfare. However, rather than being developed steadily, China's irrigation systems and agriculture have been frustrated with changes in policy-political regimes.

This paper has provided an overview of the historical paradigm shifts of agricultural IWCP and policy in China using a document-based narrative synthesis approach. The evolution of IWCP and policy regimes were divided into four eras through a mixed method that combines document 
analysis and piecewise linear regression: (1) the early post-war development period (1949-1957), during which policy reforms and economic development were implemented to consolidate political power; (2) the period of unsustainable expansion and sociopolitical interruptions (1958-1979); (3) the period of gradual development (1980-2004) when water-saving irrigation policies and strategies were introduced; and (4) the transformation period (2005-present) during which sustainable irrigation and agricultural development were emphasized. The historical evolution of China's agricultural irrigation development and changes in policy paradigms illustrate the government's growing awareness that sustainability of water use is critical in its agricultural practices.

However, as the government transforms IWCP, the legacies from the inappropriate policies of the 1960s and 1970s, such as the Great Leap Forward and Cultural Revolution, have emerged as urgent issues to be tackled, including deteriorating infrastructure, conflict between the benefits and obligations related to irrigation facilities, and financial policy coordination between different levels of government. In addressing these challenges, policy changes are needed to clarify the financial accountability of the government at all levels, to raise subsidies for the construction and management of small-scale IWCP, and to establish local non-profit organizations to enhance co-management between farmers and government.

Supplementary Materials: The following are available online at http://www.mdpi.com/2071-1050/11/24/7027/s1, Table S1: Rural and urban population from 1950 to 2018, Table S2: Numbers of local migrant workers and nonlocal migrant workers from 2010 to 2018, Table S3: Percentages of locals engaged in agriculture, locals engaged in non-agriculture and nonlocals engaged in non-agriculture, Table S4: Area of effective irrigated areas of farmland and crop yield from 1950 to 2018, Table S5: Area of saved irrigated areas from 1998 to 2018, Table S6: Revenue of central government and local government from 1950 to 2018, Table S7: Per capita wage income and per capita agricultural income from 1985 to 2018.

Author Contributions: L.D. and L.X. initiated the idea and made the draft of the manuscript. Y.L. and C.L. provided data resources and made comments for the initial draft. Z.L. and J.S.W. participated in the discussions and assisted with the first drafting. All authors have contributed to the completion of this manuscript.

Funding: This work was supported by the National Key Research and Development Program of China (2016YFC0400107-2), and the Belt and Road Special Foundation of the State Key Laboratory of Hydrology-Water Resources and Hydraulic Engineering, China (2018491811-2018zd18).

Acknowledgments: L.X., Y.L., Z.L., and J.W. would like to thank for the financial support of the Global Institute for Water Security at the University of Saskatchewan.

Conflicts of Interest: The authors declare no conflict of interest.

\section{References}

1. UN. UN adopts new Global Goals, charting sustainable development for people and planet by 2030. In United Nations Department of Economic and Social Affairs; UN: New York, NY, USA, 2015; Volume 51, pp. 84-85. [CrossRef]

2. FAO. Food and Agriculture Driving Action Across the 2030 Agenda for Sustainable Development; FAO: Rome, Italy, 2017; Volume 10, pp. 304-310.

3. FAO. Agriculture, Food and Water; FAO: Rome, Italy, 2003.

4. FAO. The State of the World's Land and Water Resources for Food and Agriculture (SOLAW)—Managing Systems at Risk; FAO: Rome, Italy, 2011.

5. FAO. The Irrigation Challenge: Increasing Irrigation Contribution to Food Security Through Higher Water Productivity from Canal Irrigation Systems; FAO: Rome, Italy, 2003.

6. Rodell, M.; Famiglietti, J.S.; Wiese, D.N.; Reager, J.T.; Beaudoing, H.K.; Landerer, F.W.; Lo, M.H. Emerging trends in global freshwater availability. Nature 2018, 557, 651-659. [CrossRef] [PubMed]

7. Liu, J.; Zang, C.; Tian, S.; Liu, J.; Yang, H.; Jia, S.; You, L.; Liu, B.; Zhang, M. Water conservancy projects in China: Achievements, challenges and way forward. Glob. Environ. Chang. 2013, 23, 633-643. [CrossRef]

8. Liu, J.; Hull, V.; Godfray, H.C.J.; Tilman, D.; Gleick, P.; Hoff, H.; Pahl-Wostl, C.; Xu, Z.; Chung, M.G.; Sun, J.; et al. Nexus approaches to global sustainable development. Nat. Sustain. 2018, 1, 466-476. [CrossRef]

9. Albrecht, T.R.; Crootof, A.; Scott, C.A. The Water-Energy-Food Nexus: A systematic review of methods for nexus assessment. Environ. Res. Lett. 2018, 13, 043002. [CrossRef] 
10. Cairns, R.; Krzywoszynska, A. Anatomy of a buzzword: The emergence of 'the water-energy-food nexus' in UK natural resource debates. Environ. Sci. Policy 2016, 64, 164-170. [CrossRef]

11. Leck, H.; Conway, D.; Bradshaw, M.; Rees, J. Tracing the water-energy-food nexus: Description, theory and practice. Geogr. Compass 2015, 9, 445-460. [CrossRef]

12. Hoff, H. Understanding the Nexus: Background Paper for the Bonn2011 Nexus Conference; SEI: Oaks, PA, USA, 2011.

13. Bazilian, M.; Rogner, H.; Howells, M.; Hermann, S.; Arent, D.; Gielen, D.; Steduto, P.; Mueller, A.; Komor, P.; Tol, R.S.; et al. Considering the energy, water and food nexus: Towards an integrated modelling approach. Energy Policy 2011, 39, 7896-7906. [CrossRef]

14. Endo, A.; Tsurita, I.; Burnett, K.; Orencio, P.M. A review of the current state of research on the water, energy, and food nexus. J. Hydrol. Reg. Stud. 2017, 11, 20-30. [CrossRef]

15. Pittock, J.; Hussey, K.; McGlennon, S. Australian climate, energy and water policies: Conflicts and synergies. Aust. Geogr. 2013, 44, 3-22. [CrossRef]

16. Biggs, E.M.; Bruce, E.; Boruff, B.; Duncan, J.M.; Horsley, J.; Pauli, N.; McNeill, K.; Neef, A.; Van Ogtrop, F.; Curnow, J.; et al. Sustainable development and the water-energy-food nexus: A perspective on livelihoods. Environ. Sci. Policy 2015, 54, 389-397. [CrossRef]

17. Momblanch, A.; Papadimitriou, L.; Jain, S.K.; Kulkarni, A.; Ojha, C.S.; Adeloye, A.J.; Holman, I.P. Untangling the water-food-energy-environment nexus for global change adaptation in a complex Himalayan water resource system. Sci. Total Environ. 2019, 655, 35-47. [CrossRef] [PubMed]

18. FAO. The Water-Energy-Food Nexus: A New Approach in Support of Food Security and Sustainable Agriculture; FAO: Rome, Italy, 2014.

19. Brooks, N.; Grist, N.; Brown, K. Development futures in the context of climate change: Challenging the present and learning from the past. Dev. Policy Rev. 2009, 27, 741-765. [CrossRef]

20. Rickards, L.; Howden, S.M. Transformational adaptation: Agriculture and climate change. Crop Pasture Sci. 2012, 63, 240-250. [CrossRef]

21. Nakamura, S.; Oki, T. Paradigm shifts on flood risk management in Japan: Detecting triggers of design flood revisions in the modern era. Water Resour. Res. 2018, 54, 5504-5515. [CrossRef]

22. Allen, C.; Metternicht, G.; Wiedmann, T. Initial progress in implementing the Sustainable Development Goals (SDGs): A review of evidence from countries. Sustain. Sci. 2018, 13, 1453-1467. [CrossRef]

23. Griggs, D.; Stafford-Smith, M.; Gaffney, O.; Rockstrom, J.; Öhman, M.C.; Shyamsundar, P.; Steffen, W.; Glaser, G.; Kanie, N.; Noble, I. Sustainable development goals for people and planet. Nature 2013, 495, 305-307. [CrossRef]

24. Chen, C.; Park, T.; Wang, X.; Piao, S.; Xu, B.; Chaturvedi, R.K.; Fuchs, R.; Brovkin, V.; Ciais, P.; Fensholt, R.; et al. China and India lead in greening of the world through land-use management. Nat. Sustain. 2019, 2 , 122-129. [CrossRef]

25. UN. 2015-REN21 Version Completa; UN: New York, NY, USA, 2016.

26. Liu, J.; Li, S.; Ouyang, Z.; Tam, C.; Chen, X. Ecological and socioeconomic effects of China's policies for ecosystem services. Proc. Natl. Acad. Sci. USA 2008, 105, 9477-9482. [CrossRef]

27. Ouyang, Z.; Zheng, H.; Xiao, Y.; Polasky, S.; Liu, J.; Xu, W.; Wang, Q.; Zhang, L.; Xiao, Y.; Rao, E. Improvements in ecosystem services from investments in natural capital. Science 2016, 352, 1455-1459. [CrossRef]

28. Bryan, B.A.; Gao, L.; Ye, Y.; Sun, X.; Connor, J.D.; Crossman, N.D.; Stafford-Smith, M.; Wu, J.; He, C.; Yu, D.; et al. China's response to a national land-system sustainability emergency. Nature 2018, 559, 193-204. [CrossRef]

29. Yu, J.; Wu, J. The sustainability of agricultural development in China: The agriculture-environment nexus. Sustainability 2018, 10, 1776. [CrossRef]

30. Coleman, W.D.; Skogstad, G.D.; Atkinson, M.M. Paradigm shifts and policy networks: Cumulative change in agriculture. J. Public Policy 1996, 16, 273-301. [CrossRef]

31. Orden, D.; Paarlberg, R.L.; Paarlberg, R.; Roe, T. Policy Reform in American Agriculture: Analysis and Prognosis; University of Chicago Press: Chicago, IL, USA, 1999.

32. Dimitri, C.; Effland, A.; Conklin, N. The 20th Century Transformation of US. Agriculture and Farm Policy The 20th Century and Farm Policy: Economic Information Bulletin Number 3. 2005. Available online: https://www.ers.usda.gov/publications/pub-details/?pubid=44198 (accessed on 2 December 2019). 
33. Garzon, I. Reforming the Common Agricultural Policy: History of a Paradigm Change; Palgrave Macmillan: London, UK, 2006. [CrossRef]

34. Chen, X. Review of China's agricultural and rural development: Policy changes and current issues. China Agric. Econ. Rev. 2009, 1, 121-135. [CrossRef]

35. Glaeser, B. Environment, Development, Agriculture: Integrated Policy through Human Ecology; Routledge: Abingdon, UK, 2016.

36. Greenhalgh, T.; Robert, G.; Macfarlane, F.; Bate, P.; Kyriakidou, O.; Peacock, R. Storylines of research in diffusion of innovation: A meta-narrative approach to systematic review. Soc. Sci. Med. 2005, 61, 417-430. [CrossRef] [PubMed]

37. Snilstveit, B.; Oliver, S.; Vojtkova, M.; Snilstveit, C.B.; Oliver, S. Narrative approaches to systematic review and synthesis of evidence for international development policy and practice. J. Dev. Eff. 2012, 4, 409-429. [CrossRef]

38. Morestin, F.; Gauvin, F.-P.; Hogue, M.-C.; Benoit, F. Method for Synthesizing Knowledge about Public Policies; National Collaborating Centre Healthy for Public Policy: Montréal, QC, Canada, 2010.

39. China Institute of Urban and Rural Economic Construction. The Construction Memorabilia of China (1949-1983); Construction Economics Magazine Press: Beijing, China, 1984.

40. Ministry of Water Conservancy. Brief History of China's Agricultural Irrigation and Water Conservancy (1949-1998); China Water \& Power Press: Beijing, China, 1999.

41. Compilation and Translation Bureau of the CPC Central Committee. Chronicle of Events of the People's Republic of China 1949-2019; People's Publishing House: Beijing, China, 2019.

42. Yang, X.J. China's Rapid Urbanization. Science 2013, 342, 310. [CrossRef] [PubMed]

43. Ministry of Water Resources of PRC. China Water Statistical Yearbook 1980-2018; China Waterpower Press: Beijing, China, 1981-2019.

44. Bureau, S.S. China Statistical Yearbook 1985; China Statistics Press: Beijing, China, 1986.

45. Bureau, S.S. China Statistical Yearbook 2012; China Statistics Press: Beijing, China, 2013.

46. Bureau, S.S. China Statistical Yearbook 2018; China Statistics Press: Beijing, China, 2019.

47. Keung Wong, D.F.; Li, C.Y.; Song, H.X. Rural migrant workers in urban China: Living a marginalised life. Int. J. Soc. Welf. 2007, 16, 32-40. [CrossRef]

48. National Bureau of Statistics of PRC. Report on Number, Structure and Characteristics of the New Generation of Migrant Workers. 2011. Available online: http://www.stats.gov.cn/ztjc/ztfx/fxbg/201103/t20110310_16148. html (accessed on 15 February 2019).

49. National Bureau of Statistics of PRC. 2016 Survey Report of Migrant Workers. 2017. Available online: http://www.stats.gov.cn/tjsj/zxfb/201704/t20170428_1489334.html (accessed on 15 February 2019).

50. Mwangi, M.; Kariuki, S. Factors determining adoption of new agricultural technology by smallholder farmers in developing countries. J. Econ. Sustain. Dev. 2015, 6, 208-216.

51. Guo, Y. Vigorously building high standard farmland to promote high quality development of agriculture. Newsl. Work Rural Areas. 2019, 1, 35-38.

52. State Council of China. Regulations on the Control of Expenses and Compulsory Labor Service Imposed on Farmers. Gaz. State Counc. PRC 1991, 41, 1430-1435.

53. Ministry of Water Resources of PRC. 2009 China Water Resources Bulletin; Ministry of Water Resources of PRC: Beijing, China, 2010.

54. Smit, B.; Cai, Y. Climate change and agriculture in China. Glob. Environ. Chang. 1996, 6, 205-214. [CrossRef]

55. Jun, X.I.A.; Chen, Y.D. Water problems and opportunities in the hydrological sciences in China. Hydrol. Sci. J. 2001, 46, 907-921. [CrossRef]

56. FAO. Global Map of Irrigation Areas (GMIA): AQUASTAT; FAO: Rome, Italy, 2013.

57. Zhang, C.; Anadon, L.D. A multi-regional input-output analysis of domestic virtual water trade and provincial water footprint in China. Ecol. Econ. 2014, 100, 159-172. [CrossRef]

58. Wang, J.; Rothausen, S.G.; Conway, D.; Zhang, L.; Xiong, W.; Holman, I.P.; Li, Y. China's water-energy nexus: Greenhouse-gas emissions from groundwater use for agriculture. Environ. Res. Lett. 2012, 7, 14035. [CrossRef]

59. Chen, D.; Yu, Q.; Hu, Q.; Xiang, M.; Zhou, Q.; Wu, W. Cultivated land change in the Belt and Road Initiative region. J. Geogr. Sci. 2018, 28, 1580-1594. [CrossRef] 
60. Liu, H. Grain transportation from North to South, production and marketing cooperation goes deep. Econ. Dly. 2017, 2, 11.

61. Wang, Y.H.; Huang, Y.X.; Tang, X. Division of China water conservancy development stages: Theoretical framework and evaluation. J. Nat. Resour. 2013, 28, 922-930.

62. Gu, H. A Study on China's Water Conservancy Modernization Process; China Water \& Power Press: Beijing, China, 2004.

63. Duckett, J.; Wang, G. Why do authoritarian regimes provide public goods? Policy communities, external shocks and ideas in China's rural social policy making. Eur. Asia Stud. 2017, 69, 92-109. [CrossRef]

64. CIDDC; CRDW. Contrastive Study on Farmland Water Conservancy Construction and Management at Home and Abroad. 2014. Available online: http://www.jsgg.com.cn/Index/Display.asp?NewsID=19656 (accessed on 2 December 2019).

65. Bureau, S.S. China Statistical Yearbook 1991; China Statistics Press: Beijing, China, 1991.

66. Wang, D. Grassroots operation of farmland and water conservancy construction movement during the great leap forward period: A study centered on Jinhua District, Zhejiang Province. Res. Teach. Party Hist. 2017, 3 , 67-76.

67. Li, W.; Yang, D. The great leap forward: Anatomy of a central planning disaster. J. Polit. Econ. 2005, 113, 840-877. [CrossRef]

68. Bureau, S.S. China Statistical Yearbook 1979; China Statistics Press: Beijing, China, 1979.

69. Li, D.X. China's Irrigation Development Policy. China's Rural Water Resour. Hydropower 2009, 6, 1-2.

70. Zhu, G. The impact of fiscal and tax system reform on rural development. China Rural Obs. 1995, 4, 14-20.

71. Wei, Y. Fiscal systems and uneven regional development in China, 1978-1991. Geoforum 1996, 27, 329-344. [CrossRef]

72. Liu, R.C.; Ma, J. China's fiscal and taxation system reform: Basic experiences and major enlightenments. Public Financ. Res. 2000, 11, 1-9.

73. Bureau, S.S. Department of Rural \& Social Economic Survey: Three Decades of Reform and Opening Up: The Compilation of Agricultural Statistics; China Statistics Press: Beijing, China, 2009.

74. Bureau, S.S. China Statistical Yearbook 2017; China Statistics Press: Beijing, China, 2017.

75. Wang, Y.H.; Sun, S.J. Analysis on income structure of farmers and increasing farmers' income. Prod. Res. 2009, 12, 42-44.

76. Armitage, D. Governance and the commons in a multi-level world. Int. J. Commons 2008, 2, 7-32. [CrossRef]

77. Ongaro, E.; Gong, T.; Jing, Y. Toward Multi-Level Governance in China? Coping with complex public affairs across jurisdictions and organizations. Public Policy Adm. 2019, 34, 105-120. [CrossRef]

78. Hensengerth, O.; Lu, Y. Emerging environmental Multi-Level Governance in China? Environmental protests, public participation and local institution-building. Public Policy Adm. 2018, 34, 121-143. [CrossRef]

79. Ye, X.Q. The transformation of China's agricultural support policy: From increasing production to enhancing competitiveness. Reforms 2017, 3, 19-34.

80. Kou, R.; Li, P.; Tan, X.Y. Analysis of the factors affecting the income distribution of migrant workers. Issues Agric. Econ. 2007, 9, 72-76.

81. Wang, X.L. China's fiscal system reform: Institution evolution and optimization. Rev. Econ. Res. 2009, 45, 2-11.

82. Yep, R. Can "Tax-for-Fee" reform reduce rural tension in China? The process, progress and limitations. China Q. 2004, 177, 42-70. [CrossRef]

83. Berkes, F. Evolution of co-management: Role of knowledge generation, bridging organizations and social learning. J. Environ. Manag. 2009, 90, 1692-1702. [CrossRef]

84. Armitage, D.; Berkes, F.; Doubleday, N. Adaptive Co-Management: Collaboration, Learning, and Multi-Level Governance; UBC Press: Vancouver, BC, Canada, 2007.

85. Plummer, J.; Taylor, J.G. Community Participation in China: Issues and Processes for Capacity Building; Routledge: Abingdon, UK, 2013.

86. Berkes, F.; George, P.; Preston, R.J. Co-Management: The Evolution in Theory and Practice of the Joint Administration of Living Resources. Alternatives 1991, 18, 12-18. 
87. Li, Z.C. Participatory Irrigation Management by Farmers-Local Incentives for Self-Financing Irrigation and Drainage Districts in China. World Bank Working Paper. 2010. Available online: http://documents.worldbank. org/curated/en/524611468025447303/pdf/453240ENGLISH0110Aug061020030pim1en.pdf (accessed on 10 November 2019).

88. Oi, J.C. Fiscal reform and the economic foundations of local state corporatism in China. World Polit. 1992, 45, 99-126. [CrossRef]

89. Qu, F.; Heerink, N.; Wang, W. Land administration reform in China: Its impact on land allocation and economic development. Land Use Policy 1995, 12, 193-203. [CrossRef]

90. Liu, S.C. Problems and countermeasures in farmland water conservancy facilities construction in China. Macroeconomics 2011, 8, 40-44.

91. Fang, X.; Zhang, X.S. Rural infrastructure construction and farmers' income growth. Prod. Res. 2009, 11, 42-43.

92. Zhou, X.P.; Liu, X.H. Discussion on the nature and management mode of irrigation and water conservancy projects in China. Yellow River 2007, 3, 53-54.

(C) 2019 by the authors. Licensee MDPI, Basel, Switzerland. This article is an open access article distributed under the terms and conditions of the Creative Commons Attribution (CC BY) license (http://creativecommons.org/licenses/by/4.0/). 